NBER WORKING PAPER SERIES

USING ELECTORAL CYCLES IN

POLICE HIRING TO ESTIMATE THE

EFFECT OF POLICE ON CRIME

Steven D. Levitt

Working Paper No. 4991

\author{
NATIONAL BUREAU OF ECONOMIC RESEARCH \\ 1050 Massachusetts Avenue \\ Cambridge, MA 02138 \\ January 1995
}

I would like to thank Josh Angrist, David Cutler, Edward Glaeser, Austan Goolsbee, Jon Gruber, Dan Kessler, John Lott, James Poterba, James Q. Wilson, two extremely helpful anonymous referees, and seminar participants at M.I.T. and Stanford for helpful comments and suggestions. Financial support of the National Science Foundation is gratefully acknowledged. This paper is part of NBER's research program in Public Economics. Any opinions expressed are those of the author and not those of the National Bureau of Economic Research.

(C) 1994 by Steven D. Levitt. All rights reserved. Short sections of text, not to exceed two paragraphs, may be quoted without explicit permission provided that full credit, including $($ ) notice, is given to the source. 


\title{
USING ELECTORAL CYCLES IN \\ POLICE HIRING TO ESTIMATE THE \\ EFFECT OF POLICE ON CRIME
}

\begin{abstract}
Previous empirical studies have typically uncovered little evidence that police reduce crime. One problem with those studies is a failure to adequately deal with the simultaneity between police and crime: while police may or may not reduce crime, there is little doubt that expenditures on police forces are an increasing function of the crime rate. In this study, the timing of mayoral and gubernatorial elections is used to identify the effect of police on crime. This paper first demonstrates that increases in the size of police forces disproportionately occur in mayoral and gubernatorial election years, a relationship that had previously gone undocumented. After controlling for changes in government spending on other social programs, there is little reason to think that elections will be otherwise correlated with crime, making elections ideal instruments. Using a panel of large U.S. cities from 1970-1992, police are shown to reduce crime for six of the seven crime categories examined. Each additional police officer is estimated to eliminate eight to ten serious crimes. Existing estimates of the costs of crime suggest that the social benefit of reduced crime is approximately $\$ 100,000$ per officer per year, implying that the current number of police is below the optimal level.
\end{abstract}

Steven D. Levitt Harvard Society of Fellows 78 Mount Auburn Street Cambridge, MA 02138 and NBER 
Crime is a major social and economic issue in the United States. The cost of crime to victims is estimated at approximately $\$ 200$ billion per year (Miller, Cohen, and Rossman 1993). The indirect costs of crime are also substantial. Government outlays on the criminal justice system totaled $\$ 74$ billion in 1990 , including $\$ 32$ billion on police protection. Private expenditures on self-protection are on the same order of magnitude.

Following the seminal contribution of Becker (1968), a large literature has addressed issues of criminal behavior and sanctions (e.g., Stigler 1970, Ehrlich 1973, Witte 1980, Myers 1983, McCormick and Tollison 1984, Andreoni 1991). One of the most surprising empirical results in this literature is the repeated failure to uncover evidence that an increase in the number of police reduces the crime rate. Of the twenty-two studies surveyed by Cameron (1988) that attempt to estimate a direct relationship between police and crime using variation across cities, eighteen find either no relationship or a positive (i.e. incorrectly signed) relationship between the two. ${ }^{1}$

There are many reasons to suspect that existing estimates of the relationship between police and crime are biased against finding that police reduce crime. The primary source of bias is the clear simultaneity between police and crime rates (Fisher and Nagin 1978). ${ }^{2}$ If more

1 In addition to cross-sectional studies, there are two other sources of evidence. Quasiexperimental evidence from a study performed in Kansas City in the early 1970's found no statistically significant difference in crime when the number of police assigned to fifteen different patrol beats were varied (Kelling et al. 1974). Analysis of police on the New York subway system in the 1960's suggests that an increased police presence reduces the number of robberies slightly, but at an extremely high taxpayer cost per crime eliminated (Wilson 1983). Also, Tauchen et al. (1993) find a deterrent effect of police resources in an analysis that combines individual-level information on arrests with aggregate information on police.

2 In fact, in a recent survey of the effect of police on crime, Sherman (1992) dismisses studies of the level of police resources based on cross-sectional variation in a footnote due to this 
police are hired when crime is increasing, a positive correlation between police and crime can emerge, even if police reduce crime. The 1994 Crime Bill provides a good case study. In response to opinion polls ranking crime as the number one problem facing the country, a crime bill authorizing funding for an additional 100,000 police officers was passed into law.

Similarly, the presence of unobserved heterogeneity across cities will impart an upward bias on cross-sectional estimates of police effectiveness. Cities that have a high level of underlying criminality are likely to have both high crime rates and large police forces. Detroit, for instance, has twice as many police officers per capita as Omaha, and a violent crime rate over four times as high, but it would be a mistake to attribute the differences in crime rates to the presence of the police.

A final source of bias against finding that police reduce crime is the use of reported crimes rather than actual crimes in empirical studies, due to the lack of availability of the true measure. Victimization surveys find that only thirty-eight percent of all crimes are reported to the police. Even for a serious crime such as robbery, reporting rates are only 54.5 percent. $^{3}$ As the police presence increases, reporting rates may rise if the perceived likelihood of a crime being solved increases. Furthermore, police officers have a great deal of discretion in choosing whether or not to make arrests in many cases such as domestic disputes. It is possible that the likelihood of arrest for a given incident decreases with the officer's workload, which may in turn be a function of the level of police staffing.

criticism, instead focusing on policing strategies.

${ }^{3}$ Definitions of the crime categories used in this study, the same as those employed by the FBI in gathering Uniform Crime Reports, are presented in the appendix. 
This paper develops a methodology that goes well beyond the existing literature on the topic in dealing with the first two sources of bias: simultaneity and unobserved heterogeneity. ${ }^{4}$ The primary innovation of the paper is the way in which it deals with the simultaneity between police and crime. In order to identify the effect of police on crime, a variable is required that is correlated with changes in the police force, but does not belong directly in the crime "production function." The instruments employed in this paper are the timing of mayoral and gubernatorial elections.

Section II of this paper documents an electoral cycle in police force staffing that was previously unrecognized in the literature. Increases in the size of police forces in large cities are disproportionately concentrated in mayoral and gubernatorial election years. For instance, the mean percentage change in sworn police officers for the cities in my sample is $2.6 \%$ in gubernatorial election years, $2.2 \%$ in mayoral election years, and only $0.4 \%$ in non-election years. That relationship persists after controlling for a variety of demographic, socio-economic and economic factors.

If elections are to serve as valid instruments, then they must be uncorrelated with crime, except through variables that are included in the equation explaining crime. The most obvious ways in which elections might systematically affect the crime rate (other than through changes in the police force) are through electoral cycles in other types of social spending, or through politically induced fluctuations in economic performance. Consequently, spending on education and public welfare programs are included in the equations, as are state unemployment rates.

4 Unfortunately, data restrictions make it impossible to adequately address the bias from changes in reporting behavior in the current analysis. To the extent that reporting bias in present, the results of this paper understate the effectiveness of police. 
Having controlled for those factors, it seems plausible to argue that election timing will be otherwise unrelated to crime. Tests of overidentifying restrictions support that claim.

The second source of bias in estimates of police effectiveness, unobserved heterogeneity in underlying criminality across cities and over time, is dealt with in three ways. First, concerns over differences across cities are eliminated by including city-fixed effects in all specifications so that the parameters are identified only using within-city variation over time. Secondly, citylevel trends are also included to account for the fact that some cities have become more dangerous over time, while others have not. These city-level trends explain a substantial portion of the variance in crime rates. Furthermore, their inclusion has a large effect (in the predicted direction) on estimates of police effectiveness, lending support to the claim that the number of police responds to rising and falling crime rates in a city. Third, socio-economic and demographic controls are included in the analysis to capture variation in a city's population over time. These controls included the percent of the population that is black, the percent of female headed households, and the percent of the population between the ages of 15 and 24 (the age group most likely to engage in criminal activities).

The results of the paper, based on a panel of 59 large cities over the period 1970-1992, ${ }^{5}$ suggest that swom police officers reduce crime, and the magnitude of that reduction is both substantively important and statistically significant. Point estimates are negative for six of the seven crime categories examined (murder and non-negligible manslaughter, forcible rape, assault, robbery, burglary, larceny, and motor vehicle theft). Larceny is the only crime that has

5 These cities represent all U.S. cities with directly elected mayors and a population of over 250,000 at some point in the time period analyzed. 
an unexpected (but statistically insignificant) positive sign. The elasticities of crime with respect to the number of sworn officers range from 0.06 to -1.23 across the various crimes. Civilian employees of police forces, in contrast, appear to have a negligible effect on reported crime.

Estimated at the means of the data, each additional sworn police officer reduces the number of crimes across the various categories by eight to ten per year. Using estimates of the costs of crime to victims developed by Cohen (1988) and Miller, Cohen, and Rossman (1993), the value to society of eliminating those crimes is approximately $\$ 90,000-\$ 130,000$ per officer per year, suggesting that the current number of police officers in large cities is below the socially optimal level.

While the particular focus of this paper is on the issue of police and crime, the methodology employed here, namely the use of political variation to identify the effects of public policies, may prove to be of much broader applicability. Because public policies emerge from a political process, electoral cycles and differences in political institutions are logical instruments for public policy changes. To the extent that the timing of elections and political institutions are relatively fixed, such instruments may provide a more plausibly exogenous source of variation than either cross-sectional or time-series analyses.

The outline of the paper is as follows. Section I summarizes the data set used in the analysis. The second section demonstrates a positive correlation between changes in the size of the police force and both city mayoral races and gubernatorial elections. Section III presents the estimates of the effect of police on crime using the variation in police staffing due to electoral cycles to identify the parameters. Section IV attempts to place a social value on the reduction in crime, and considers the public policy implications of the results. Section V offers 
a brief conclusion.

\section{Section I: The Data}

The data used are a panel of 59 U.S. cities, with observations running from 1970-1992. These cities represent all U.S. cities satisfying two criteria: (i) the city population exceeds 250,000 at some point in the time period analyzed, and (ii) the mayor is directly elected. Because mayoral elections are critical to identifying the model, six cities (Cincinnati, Virginia Beach, Norfolk, Wichita, Santa Ana, and Colorado Springs) that satisfy the population cut-off, but do not have direct election of mayors, are excluded from the sample.

Data on crime are taken from the Uniform Crime Reports published by the FBI, and are available annually on a city-level basis for seven types of crime: murder and nonnegligent manslaughter, forcible rape, assault, robbery, burglary, larceny, and motor vehicle theft. Precise definitions of the crimes are presented in the appendix. Data on the number of police, both sworn officers and civilians employees, are also taken from the FBI Uniform Crime Reports. Sworn officers carry a gun and have the power of arrest; civilian employees do not.

Summary statistics on police and crime for the cities in the sample, expressed in values per 100,000 population, are presented in Table 1. Overall, there is slightly less than one reported crime per ten individuals, the majority of which are relatively minor property crimes. ${ }^{6}$ Violent crime rates for the cities in the sample are more than twice as high as for the nation as

6 In fact, this number greatly understates the true crime rate for two reasons. First, less than half of all crimes are reported to the police. Secondly, when multiple offenses occur in the commission of a single crime, the FBI only records the most serious of these offenses. Thus, if a robber kills someone in the process of a hold-up, and then steals a car to flee the scene, only the murder would be included in the FBI statistics. 
a whole; property crimes per capita are almost twice as frequent in these cities. One notable feature of the data on reported crime is the wide variation across cities. The crime rates for an individual crime category often vary by orders of magnitude across cities. While some of this variation is probably attributable to differences in crime definitions and reporting, the variation is nonetheless striking. ${ }^{7}$ There are almost 300 police per 100,000 population, approximately $80 \%$ of whom are sworn officers.

Figure 1 shows the time series (in per capita terms) of violent crime, property crime, and sworn officers for the cities in the sample. In each case, the 1970 value of the category is indexed as 100 . Violent crime has seen the greatest increase, more than doubling in these cities between 1970 and 1992 . Until the mid 1980's, violent crime and property crime tracked each other fairly closely. Since that time, violent crime has steadily increased, while property crime has flattened. ${ }^{8}$ The number of sworn officers has grown less rapidly than crime rates.

In addition to the data on police and crime, a number of demographic, government spending, and economic variables are included in the regressions. Ideally, those variables would be available at

the city-level on an annual basis. Unfortunately, the data limitations with respect to city-level data necessitate a number of compromises. While city populations are available annually, the only convenient data source for the percent of a city's population that is black and the percent

${ }^{7}$ Glaeser, Sacerdote, and Scheinkman (1994) undertake an in-depth analysis of this issue.

8 Victimization surveys, unlike the reported crime statistics used in this analysis, show a declining trend in crime rates per capita (for the nation as a whole). Unfortunately, more disaggregated data on victimization is not available. For an extensive discussion of crime data in the United States, see O'Brien (1985). 
living in female headed households is the decennial census. Consequently, a linear interpolation of those variables is made for non-census years. Since demographic variables tend to evolve slowly, this may serve as a reasonable approximation. The data on the percentage of the population between the ages of 15 and 24 used in this paper is also linearly interpolated from the decennial census, and suffers from the further defect that it is defined at the SMSA rather than city level.

Data on government spending for education and public welfare programs has a different complication. While annual city government outlays on such programs are available, less than ten percent of total state and local expenditures on both of those categories originate at the city level. ${ }^{9}$ State outlays, however, are not broken down according to the city that receives the money. Therefore, the spending variables that are employed in this paper are combined state and local outlays per capita (in 1992 dollars) on a particular category in a given state and year. While this variable misses some of the city-level variation, it is assumed that any mayoral election cycles in such spending will be small since city budgets for such activities are also small. Finally, annual state unemployment rates are used to control for economic fluctuations. Summary statistics for the various control variables described above are presented in Table 2.

\section{Section II: Mayoral and Gubernatorial Election Cycles in Police Staffing}

There are many reasons to suspect a link between elections and the timing of changes in the size of city police forces, particularly in big cities. First, crime is a critical political issue

9 In 1992, only eight of the fifty-nine cities in the sample spent an appreciable amount on education. Local school boards are typically financed independently from city governments. 
in these cities, and has been since the crime rate began to rise in the early 1960 s. Crime consistently ranks among the most important issues facing the nation in opinion surveys, and is frequently the most critical issue when the economy is performing well. Given the importance of crime as a political issue, incumbents will have incentives to increase the police force in advance of elections, either in hopes of actually reducing crime, or simply to demonstrate that they are "tough on crime. ${ }^{10}$

For mayors, especially, police are an ideal target for political manipulation since police departments are organized at the city level with only a few exceptions. ${ }^{11}$ That both gives ultimate decision-making authority on police issues to the mayor, and also means that credit or blame concerning police performance are easily traced to the mayor by voters. Furthermore, the high rate of turnover among police officers (who can typically retire after 20 years with a full pension) and the ease of altering the size of an incoming class of cadets makes both upward and downward shifts in the size of the police force easy to accomplish. In contrast, a city's economic performance is largely outside the control of the mayor. For that reason, it is not clear that voters hold mayors responsible for a city's economic situation; Chubb (1988) finds that even governors bear little responsibility for the state economy in the eyes of voters.

While the motives of incumbent governors are likely to be similar to those of incumbent mayors, the mechanism by which governors might affect levels of city police staffing are less straightforward since the state government does not typically directly hire local police. State

${ }^{10}$ Monkkonen (1992) details various other political uses of urban police forces over the last century, although no mention is made of election cycles in police staffing.

11 In recent years, a few cities have formed a joint force with surrounding communities. Nashville, for instance, shares its police force with Davidson County. 
governments do, however, provide substantial local aid to city governments (representing more than 20 percent of general revenues for large cities), as well as a more limited amount of intergovernmental grants tied specifically to local law enforcement. Besley and Case (1994) document gubernatorial election cycles for a range of fiscal variables. Although intergovernmental grants is not among the categories Besley and Case (1994) examine, the existence of cycles in intergovernmental grants would not be implausible in light of their other results.

Empirically, changes in the size of police forces do indeed tend to mirror the political cycle in large cities. A simple comparison of the mean percentage change in the number of police officers in the sample across election and non-election years reflects this pattern (standard deviations in parentheses):

$\begin{array}{lll}\% \Delta \text { Overall } & \% \Delta \text { Sworn } & \% \Delta \text { Civilian } \\ \text { Police } & \text { Officers } & \text { Employees }\end{array}$

$\begin{array}{lccc}\begin{array}{l}\text { Gubernatorial } \\ \text { Election Year }\end{array} & 2.8 & 2.6 & 4.5 \\ (\mathrm{~N}=349) & (0.3) & (0.3) & (1.1) \\ \text { Mayoral } & & & \\ \begin{array}{l}\text { Election Year } \\ (\mathrm{N}=402)\end{array} & 2.8 & 2.2 & 5.1 \\ & (0.3) & (0.3) & (1.0) \\ \text { No Election } & & & \\ (\mathrm{N}=629) & 0.7 & 0.4 & 2.2 \\ & (0.2) & (0.2) & (0.9)\end{array}$

Overall, police forces grow by 2.8 percent on average (with a standard error of 0.3 ) in 
either gubernatorial or mayoral election years, but only 0.7 percent (with a standard error of $0.2)$ in non-election years. ${ }^{12}$ Dividing police forces between sworn officers and civilians reveals similar patterns for both categories, although the standard errors on civilian employees are much larger.

Figure 2 provides a year-by-year comparison of increases in sworn officers for cities with elections in a given year (either mayoral or gubernatorial) and cities without elections. ${ }^{13}$ While there is substantial year-to-year variability in the average change in the number of sworn officers, cities with elections in the current year exhibit higher rates of increase (or smaller decreases) in 20 of the 23 years. If changes in sworn officers are independent across cities and are unrelated to the timing of elections, the likelihood that cities holding elections would have higher rates of increase in 20 of 23 cases is less than one in $4,000 .^{14}$

Another way of examining the robustness of the relationship between sworn officers and elections is to analyze the data on a city-by-city basis. A full list of cities, along with information on mean changes in sworn officers in gubernatorial, mayoral, and non-election years is provided in the Appendix. Excluding Washington D.C., which does not have gubernatorial elections, 43 of the 58 cities in the sample have higher mean rates of increase in gubernatorial

12 Approximately $3 \%$ of the observations in the sample have both mayoral elections and gubernatorial elections in the same year. Consequently, there is a small amount of doublecounting in these simple averages. The patterns are unaltered if such observations are discarded.

13 Throughout the paper the analysis will tend to focus on sworn officers rather than civilian police employees. This is partly because of an a priori expectation that sworn officers will have a greater impact on crime, and partly because empirically the link between elections and sworn officers is stronger.

14 Of course, changes in police forces across cities are not truly independent since grants from state to local governments will tend to covary for cities in the same state. 
election years compared to years in which there are neither gubernatorial or mayoral elections. If cities represent independent observations, the odds of this pattern are less than one in 5,000 if elections do not affect police hiring. 39 of the 59 cities have greater mean increases in sworn officers in mayoral election years versus non-election years (with one tie). Again assuming independence across cities, the likelihood of this pattern is less than one in 150 if mayoral elections have no affect on police staffing.

Those simple averages, of course, do not take into account possible correlation between the timing of elections and other factors that might influence growth of the police force, such as the state of the economy. It is also possible that election cycles in police staffing exhibit a more complicated structure than simply being high in election years and low in non-election years. Different patterns may also emerge in cities that have two year mayoral terms rather than four year terms.

To incorporate those possibilities, the relationship between police and elections is modeled more formally as follows:

$$
P_{i t}=E_{i t} \theta+X_{i t} \delta+\gamma_{t}+\lambda_{i}+v_{i t}
$$

where $P_{i n}$ is the percent change in the relevant police staffing category for city $i$ in year $t, E$ is a matrix of indicator variables corresponding to the years of the mayoral and gubernatorial election cycle, and $\mathrm{X}$ is a matrix of covariates.

Table 3 presents three sets of regression estimates of equation (1) corresponding to 
overall police, sworn officers, and civilian police employees. The regressions in Table 3 allow a different intercept for each year of the election cycle for both mayoral and gubernatorial elections. The effect of mayoral election years is also allowed to vary according to whether the mayor's term is two or four years. All election coefficients are relative to the relevant omitted category, which in each case is the year directly following an election. Year indicators are included in the regressions, removing any national-level shocks to police hiring. City-fixed effects are also included; therefore the parameters are identified using only within-city variation over time.

A strong relationship between election years and police hiring continues to hold for overall police and sworn officers after controlling for the other factors. For instance, sworn officers are estimated to increase by an additional $1.3 \%$ in mayoral election years (relative to the year after the election) in cities with two year mayoral terms. For cities with four year mayoral terms, sworn officers increase by an extra 1.0 percent in election years, and also exhibit some tendency towards greater than average growth in the year prior to an election year. The individual mayoral election year coefficients are only marginally statistically significant, but are jointly significant at the .05 level in both columns (1) and (2). The largest electoral effects are for gubernatorial election years, in which sworn officers increase by an additional 3.0 percent. There is some evidence that sworn officers also increase disproportionately two years before gubernatorial elections, although there is not a strong election cycle rationalization for such a result. ${ }^{15}$

15 Following Besley and Case (1994), who find differential tax and fiscal behavior by incumbent governors conditional on the presence of binding term limits, I divided governors between those constrained from seeking re-election and those who are not constrained. While 
While the election coefficients are positive for civilian police employees, the estimates are both individually and jointly statistically insignificant due in part to imprecise estimates. That result is not surprising. To the extent that only sworn officers have a direct impact on crime, one would expect that political manipulation of police departments would be concentrated on sworn officers.

The other variables in the regression are generally statistically insignificant and carry coefficients that are substantively small. The exception to that pattern is the state unemployment rate, which has a statistically significant negative coefficient in columns (1) and (2). For each percentage point increase in unemployment, the predicted growth rate in the police force declines by over three-tenths of a percentage point.

Section IV: Estimating the Effect of Police on Crime

The preceding section demonstrates a correlation between elections and changes in the police force. In order for election timing to serve as an instrument to identify the effect of police on crime, it must also be the case that elections are validly excluded from the crime "production function." The primary reason that such an exclusion might be invalid would be a failure to control for other variables that are both correlated with crime and also affected by electoral cycles. In particular, spending on public welfare or education might fall into that category since such spending may have effects on criminal activities by changing the opportunity sets of potential criminals. It is also possible that state and local elections induce economic

there was some evidence in the raw data that unconstrained governors induce more extreme cycles in police hiring, the restriction of identical behavior could not be rejected in the specifications shown in Table 3. 
fluctuations akin to the political business cycle observed at the national level (Alesina and Sachs 1988). In estimating a relationship between police and crime, therefore, controls are included for state and local spending on both public welfare and education, as well as state unemployment rates. Having controlled for such factors, election cycles would appear to be plausible instruments.

Another potential source of upward bias in estimating a relationship between police and crime is unobserved heterogeneity across cities and over time. Three steps are taken to deal with such heterogeneity. First, city-level fixed effects are included in all specifications. Thus, the coefficients are identified using only within-city variation over time, lessening concern over the possible omission of explanatory variables that systematically vary across cities, and also avoiding the problem of non-comparability of reported crime statistics across cities ( $O^{\prime}$ Brien 1985). Second, city-level trends are included to account for the fact that large changes in the underlying criminality of a given city can occur over time. Per capita crime in Jersey City increased by over $250 \%$ between 1970 and 1992 . In contrast, San Jose saw a $30 \%$ decrease in per capita crime over the same period. For all of the crime categories examined, the city trends are jointly statistically significant at the .01 level, as are the city-fixed effects. Finally, year dummies and demographic controls are included in the analysis to further capture variation in a city's situation over time.

The effect of police on crime is allowed to enter both contemporaneously and with a oneyear lag. ${ }^{16}$ From a theoretical perspective, increases in the police force may affect crime with a lag. Police reduce crime either via deterrence (preventing the commission of the initial crime

16 Inclusion of longer lags did not substantially alter the findings. 
due to an increased likelihood of being caught), or through incapacitation (catching repeat offenders so they cannot commit future crimes). If there are lags in the response of criminal behavior to the probability of being caught, the deterrence effect will not be immediate. Similarly, the benefits of incapacitation are realized for as long as the offender is in jail. On a purely practical level, another reason for including lagged changes in the police force is the staggered nature of the available data. Data on reported crimes are collected on a calendar year basis, whereas the size of the police force is a snapshot as of October 31 st. $^{17}$ As a consequence, if changes in the police force occur shortly before October 31 st, there is little opportunity for those changes to affect crime in the current year.

The impact of police on crime is estimated using two-stage least squares, treating the police variables as endogenous and the other right-hand side variables as exogenous. The particular form of the equations to be estimated are as follows:

$$
\begin{aligned}
& C_{i t}=P_{i k} \beta+X_{i t} \eta+t \theta_{i}+\gamma_{t}+\lambda_{i}+\epsilon_{i t} \\
& P_{t t}=E_{i t} \phi_{i}+X_{i t} \delta+\gamma_{t}^{\prime}+\lambda_{i}^{\prime}+t \omega_{i}+\epsilon_{i t}^{\prime}
\end{aligned}
$$

where $C_{i t}$ is the (logged) number of crimes in a given category in city $i$ in year $t, P$ is a matrix of (logged) contemporaneous and lagged sworn and civilian police staffing variables, $\mathrm{X}$ is a

${ }^{17}$ The fact that the size of the police force is reported as of October 31st is quite fortuitous for this analysis since most mayoral elections and all gubernatorial elections occur in early November. 
matrix of covariates, and $\mathrm{E}$ is a matrix of election year indicators. Equations 2 and 3 also include year dummies, city-fixed effects, and city-level trends. The effect of police on crime is identified via the election year indicator variables that are included in the first stage equation (equation 3), but excluded from the second stage (equation 2).

In the empirical estimation, the effect of mayoral elections on police staffing is allowed to vary across cities and the effect of gubernatorial elections is allowed to vary across states. In other words, mayoral elections in Miami are allowed to have a different effect on changes in the police force than mayoral elections in Chicago, but every mayoral election in Miami is assumed to have the same effect on the police force. Gubernatorial elections are constrained to have the same effect on police in San Jose and San Francisco, but can have different effects across states. A priori, there is no reason to believe that different mayors or governors have either equal incentives or equal capability to manipulate the police force for political purposes. Further justification for allowing the effects of elections to vary across cities is that the restriction of equal $\phi$ 's across all cities in equation 3 is rejected at the .01 level for sworn officers.

There are both advantages and disadvantages to using such a large set of instruments. Allowing election cycles to vary by city exploits the available information more efficiently, leading to smaller standard errors than would be obtained with a more limited set of instruments. A second benefit of allowing electoral effects to vary by city is that it generates a large number of testable overidentifying restrictions. One cost of having so many instruments is that it may lead to estimates that are biased in the same direction as those obtained using OLS. If the true relationship between elections and the police force is identical across all cities, then allowing that 
relationship to vary by city will tend to pick up "bad" variation: cities that exhibit strong electoral fluctuations in police under that scenario will tend to be the cities that (by chance) had increases in criminality in election years. ${ }^{18}$ In the limit, where there is a separate instrument for each observation in the data set, two stage least squares is identical to OLS. A second drawback of having so many instruments is that convergence to asymptotic properties occurs slowly when the correlation between the instruments and the variables that are instrumented for is low (Staiger and Stock 1993). While that critique is unlikely to apply to the estimated coefficients on sworn police officers, where elections are good predictors of staffing changes, it may be quite relevant to the estimates on civilian employees where the explanatory power of electoral cycles is much lower.

Table 4 presents the results of two stage least squares estimation of equation (2) for each of the seven individual crime categories. In all specifications, feasible generalized least squares is used to take into account heteroskedasticity across cities. For simplicity, only the sum of the coefficients on current and lagged changes in police (as well as the appropriate standard errors) are reported. Since the dependent variable and the police variables are both in logs, those sums represent the estimated elasticity of crime for each category with respect to sworn and civilian police employees respectively.

The first row of Table 4 presents the estimated elasticity of various types of crime to sworn police officers. The point estimates range from 0.06 to -1.23 . The estimated elasticities

${ }^{18}$ Experimentation with reduced sets of instruments did not reveal any systematic tendency for the 2SLS estimates to move further away from the OLS estimates. 
are negative for six of the seven crime categories. ${ }^{19}$ Only larceny carries a positive (but statistically insignificant) coefficient. For three crime categories (murder, robbery, and motor vehicle theft), the estimates are statistically significant at the .05 level. The coefficient for rape is statistically significant at the .10 level.

In contrast to sworn officers, civilian employees appear to have little systematic effect on crime, although this result must be interpreted with caution given the poor performance of the instruments in the first stage. The estimated elasticities are evenly distributed between positive and negative signs. Interestingly, the two crime categories where civilian police have the largest negative impact are burglary and larceny, the least serious of the offenses included in the analysis, and precisely the crimes where increases in sworn officers had little impact.

Because the election cycle variables that serve as instruments are allowed to vary by city, the specifications in Table 4 are overidentified, allowing for a test of the exogeneity of the extra instruments. To test those restrictions, the residuals from the second stage regression of TSLS are regressed on all of the exogenous variables included in the specification, as well as the full set of election-cycle instruments. The test statistic for the validity of the overidentifying restrictions is computed as $N^{*} R^{2}$ where $\mathbf{N}$ is the number of observations and $R^{2}$ is the unadjusted R-squared from the regression of the residuals on the exogenous variables and the instruments. That test statistic is distributed $\chi^{2}$ with degrees of freedom equal to the number of

19 A similar pattern holds when looking at the contemporaneous and once-lagged effects of sworn officers individually, rather than at the sum of those values. For all of the crime categories except murder and larceny, the contemporaneous and once-lagged coefficients are both negative and of similar magnitudes. For murder, the contemporaneous effect of sworn officers is .03 (with a standard error of .25), whereas the lagged effect is -.66 (with a standard error of .24). For larceny, the contemporaneous effect is slightly positive, while the lagged effect is slightly negative. Both estimates are statistically insignificant. 
overidentifying restrictions, in this case 208. For all seven categories, the test statistic is well within conventional bounds. The highest value of the test statistic, obtained for murder, is significant at only the .25 level. The inability to reject the overidentifying restrictions reinforces the intuition that election cycles are a reasonable choice of instrument.

The other coefficients in Table 4 are also of interest, although the results are mixed. In six of the seven specifications, the estimated elasticity of crime with respect to population is positive, although generally less than one. The restriction implied by estimating the relationship between police and crime in per capita terms is easily rejected for all of the crime categories. ${ }^{20}$

The percentage of the population that is black is generally negatively correlated with crime, while the percentage of female headed households has a generally positive effect on crime. Because of the extremely high positive correlation between those variables $(\rho=.86)$, however, it is somewhat difficult to interpret those coefficients separately. The percentage of the population between the ages of 15 and 24 has the expected positive sign for all crimes except rape and murder. A one standard deviation change in that variable (1.5 percentage points) translates into an increase of more than $10 \%$ in the number of robberies and motor vehicle thefts, and an increase in excess of $5 \%$ for burglaries and larcenies.

Spending on public welfare programs carries a small negative coefficient across all of the specifications, implying that increased public welfare spending reduces crime. In contrast, education spending per capita has a positive effect in crime. One explanation for this result is

20 Estimating equation (2) in per capita terms is equivalent to imposing the restriction that $\beta_{5}=1-\beta_{1}-\beta_{2}-\beta_{3}-\beta_{4}$. (To see this, impose that restriction on equation (2), subtract $\ln$ (population) from both sides, and rearrange terms to obtain a per capita regression.) 
that educational spending is serving as a proxy for the age distribution of the population.

Changes in the unemployment rate appear to have a substantial effect on crimes where monetary gain is the primary motivation (robbery, burglary, larceny, and motor vehicle theft), but have little effect on "crimes of passion." A one percentage point increase in the unemployment rate leads to a jump of more than one percent in the larceny, and burglary rates. Those elasticies are generally larger than those obtained using national-level time-series data (Cantor and Land 1985, Devine et al. 1988). Evaluated at the 1992 sample means, a one percentage point increase in unemployment leads to an additional 106 reported crimes per year per 100,000 population.

In order to understand how the estimates of police impact are affected by the inclusion of city-level trends and instrumenting, Table 5 presents crime-by-crime estimates of the police coefficients from three different specifications. The first specification, presented in rows 1 and 4 , includes all of the variables in Table 4 except for city-level trends, and does not instrument with the election cycle. The second specification, in rows 2 and 5 , is identical to the first specification except that city-level trends are added. The final specification also instruments using the election variables, and is thus identical to that presented in Table 4. If unobserved heterogeneity and simultaneity are present, the coefficients should become more negative moving down the columns.

Focusing first on the top three rows corresponding to sworn officers, the effects of controlling for city-level trends and instrumenting are dramatic. In the simplest specification, all seven of the point estimates on sworn officers carry an unexpected positive sign, and the estimates are statistically significant at the .05 level in six of the seven cases. Adding city trends 
to control for unobserved variation in cities over time has a large effect on the estimates. Comparing rows 1 and 2, the point estimates are more negative for every crime category in the latter. Five of the seven estimates now have the predicted negative sign. The point estimates are statistically significant at the .05 level for three crimes (robbery, burglary, and motor vehicle theft), and are statistically significant at the .10 level for both murder and rape. Instrumenting in row 3 leads to further declines in the coefficients in five of the seven categories (but also results in standard errors approximately three times larger than those of the other specifications). It therefore appears that both unobserved heterogeneity and endogeneity of police increases have contributed to the failure of previous studies to uncover negative effects of sworn officers on crime. The effects on civilian police employees in Table 5 are much less dramatic. Adding city-level trends has no systematic effect on the coefficients. Instrumenting does tend to make the estimates more negative.

One possible criticism of the estimates presented thus far is the relatively poor data quality for many of the covariates included in Table 4. A logical question to consider, therefore, is whether the negative relationship between sworn officers and crime is an artifact of the data problems or the particular specification employed. Table 6 re-estimates equation (2) omitting all of the covariates except for city population. It is reassuring that the estimates are virtually identical for all of the crime categories except murder and rape, where the effect of sworn officers remains negative, but is reduced. As before, tests of the overidentifying restrictions are well-within accepted limits, supporting the validity of the instruments, even when no factors are controlled for in the crime equation except for year dummies, city-fixed effects, and city trends.

The negative relationship between sworn officers and crime is robust to two further 
alterations to the specification (tabular results are not provided, but full estimates are available from the author on request). First, instrumenting using only gubernatorial elections or only mayoral elections, rather than both, does not systematically affect the estimates, but does increase the standard errors. Second, inclusion of changes in other crimes as an explanatory variable in the regressions has little effect on the estimated effect of police. One might expect that changes in other crimes will better reflect changes in the underlying criminality of a city than will the crude demographic controls included in this analysis. While the coefficients on other crimes are generally positive as expected, the relationship between sworn officers and crime is unaltered.

\section{Section V: Implications of the Estimated Effects of Police on Crime for Public Policy}

While the estimates of the previous section suggest a negative relationship between sworn police officers and crime, those elasticities alone are not sufficient to determine the appropriate policy prescription. A thorough analysis of the public policy question requires careful consideration of at least four further issues. First, one must make an assumption concerning the ability of the police to affect unreported crimes. As long as criminals do not "specialize" in either reported or unreported crime, then the effect of police is likely to be similar across the two classes of crimes. In favor of that argument, a criminal does not know in advance whether a crime will be reported. It may be, however, that unreported crimes systematically differ from reported crimes (e.g., spousal assault tends to be reported less frequently than assaults at bars). If that is the case, an increased police presence may not have a large effect on unreported crimes. Secondly, a valuation must be placed on the social cost of crime. Ideally, that social 
cost would include not only the value of stolen property, but also the substantial psychic costs of crime, as well as the marginal costs of precautionary actions taken to avoid being a victim of crime (e.g., home security systems, car alarms, or avoiding Central Park after dark). ${ }^{21}$ Third, some consideration must be given to the social value of police activities that are not related to reductions in the subset of crimes considered in this paper. Less than a quarter of all arrests are for crimes included in this analysis. Among the criminal activities not included in this paper that impose substantial social costs are driving under the influence, drug-related activities, arson, fraud, and vandalism. Moreover, police spend only half of their time on crime related activities (Greene and Klockars 1991). Finally, one must assess the degree to which the estimates of this paper continue to be biased against finding effects of police due to changes in reporting behavior. ${ }^{22}$

While an exhaustive analysis of those four issues goes beyond the scope of this paper, it is nonetheless possible to derive rough estimates of a lower bound on the social benefits associated with increasing police staffing. The estimates that follow do not take into account any reporting bias, nor do they include any benefits of police activities except those related to the

${ }^{21}$ One might also consider what social weight is given to the monetary gain and/or utility of the criminal from committing the crime.

22 Empirical studies of the importance of the reporting bias range widely. Craig (1987) finds the elasticity of crime reporting with respect to the clearance rate(arrests/reported crimes) to be 0.60 , with a standard error of 0.31 , using data on Baltimore neighborhoods that combines information from the National Crime Survey and data from the Baltimore police department. Levitt (1994), in contrast, finds little or no evidence that reporting rates are a function of the number of police using victimization survey data from 26 cities. Levitt (1994) also examines changes in the ratio of murders to other crimes as the number of police changes. Under the assumption that murders are always reported, but the reporting rate of other crimes varies with the number of police, that ratio might be expected to be a declining function of the number of police. No evidence of such a decline is uncovered. 
seven crimes analyzed in this paper. Efforts are made, however, to deal with the other issues. Estimates of the number of crimes reduced by an additional police officer are presented under two alternative scenarios. In the first scenario, police are assumed to have no impact on the rate of unreported crimes. The second set of estimates assumes that the effect of police on unreported crime is identical to the effect on reported crime. The truth is likely to fall somewhere in between those two alternatives. In measuring the costs of crime, estimates provided by Cohen (1988) and Miller, Cohen, and Rossman (1993) are utilized. Those papers attempt to capture monetary costs of crime (medical bills, property loss, lost productivity) and quality of life reductions due to pain and suffering. To gauge the quality of life reductions, jury awards in civil suits, excluding punitive damages, are estimated for a wide range of injuries. Those awards are then mapped to the distribution of injuries associated with the various crime categories. These cost estimates do not include the costs of additional preventative measures taken by victims, lifestyle changes associated with the marginal crime, costs to employers, or legal costs, and therefore may understate the true costs of crime.

Table 7 presents estimates of the impact of adding one additional swom officer. The values in Table 7 are based on the estimated elasticities from Table 4, and are computed at the sample means. Column (1) is the impact of an additional officer on reported crime. Column (2) reflects the combined decrease in reported and unreported crimes, assuming that the effect of police is identical across reported and unreported crimes. Estimates of the reporting rate for each crime are based on the National Crime Survey (U.S. Department of Justice 1992).

As column (1) demonstrates, an additional sworn police officer is estimated to reduce the number of reported crimes by approximately eight per year. While the bulk of this reduction 
is due to fewer auto thefts, each officer also reduces the number of reported robberies by 1.6 per year, eliminates 0.6 assaults, and prevents a rape every eight years and a murder every twenty years. The number of reported larcenies, based on the estimates in Table 4 , are actually projected to increase. When the potential effects of police on unreported crime is also included (column 2), the number of crimes eliminated per officer per year increases only slightly, to approximately ten. Adding unreported crimes has a relatively minor effect on crimes eliminated since most of the crimes for which sworn officers are found to be effective have high reporting rates.

Columns (3) and (4) are the Cohen (1988) and Miller, Cohen, and Rossman (1993) estimates of the monetary and quality of life losses due to crime. ${ }^{23}$ For violent crimes, the bulk of the costs are associated with quality of life reductions. For property crimes, the costs are almost exclusively monetary. Column (5) combines the information in the first four columns to provide an estimate of the social value of the reduction in crime. The first value in column (5) is based only on the decrease in reported crimes in column (1); the second value is derived from the sum of columns (1) and (2). The reduction in robberies provides the greatest social

23 The Miller, Cohen, and Rossman (1993) estimates, which update Cohen (1988), are available for rape, robbery, and assault only. The Cohen (1988) estimates are therefore used for burglary, larceny, and auto theft. I diverge from Miller, Cohen, and Rossman (1993) in the determination of the cost of a murder. According to their estimates, the cost per murder (adjusted to 1992 dollars) is over $\$ 2.7$ million. Over $\$ 700,000$ of that value is for lost productivity. Following Schelling (1989), however, I do not include that value since the victim would have been the primary consumer of that lost productivity, and therefore it is not clear that society loses on net. The value Miller, Cohen, and Rossman (1993) assign to lost quality of life from per murder, almost $\$ 2$ million in 1992 dollars, similarly seems too high. Therefore, I (somewhat arbitrarily) assign a quality of life reduction of $\$ 400,000$ for each murder. It is, of course, straightforward to calculate social benefits to crime reductions under alternative valuations that the reader deems more appropriate. 
benefit. Each robbery eliminated has a social benefit of $\$ 17,800$. Including only the change in reported robberies (1.6) yields a social benefit of $\$ 28,700$ per officer; when the possible effect on unreported robberies is also included the social value roughly doubles. Reductions in the number of auto thefts also make a substantial contribution to social welfare -- on the order of $\$ 22,500$ to $\$ 30,100$ for an additional officer per year. Reduced murders represent a substantial social benefit of roughly $\$ 20,000$ per officer per year. The other violent crime categories (rape and assault) also make substantial contributions. The impact of burglary and larceny, however, is minor.

Summing across all seven categories, the estimated social benefit of each additional officer is approximately $\$ 90,000$ to $\$ 130,000 .{ }^{24}$ Given that an additional police officer will receive a salary of approximately $\$ 40,000$, and impose non-salary overhead costs of a roughly equal magnitude, ${ }^{25}$ the number of sworn officers in large cities appears to be slightly below the optimal levels. In all likelihood, the estimates above understate the true social value of police due to changes in reporting behavior, the focus on a limited subset of crimes, and the omission of important components of the overall costs of crime, further reinforcing the conclusion that

${ }^{24}$ To get a rough estimate of the precision of the social cost estimates, standard errors were computed assuming that the costs per crime were exact and that the estimates of the effect of police on the different crime categories were uncorrelated. Both of those assumptions will lead the computed standard errors to understate the true values. The estimated standard error on the social benefits to an additional police officer are $\$ 17,900$ when only reported crimes are included, and $\$ 29,200$ when both reported and unreported crimes are included.

25 Donohue and Siegelman (1994) report that there were 812,000 state and local police employees in 1990 , and total salary expenditure for this group was $\$ 33.4$ billion in 1990 , for an average salary of $\$ 41,000$. The shadow cost of raising public funds should also be included in the calculation of the overall cost of an additional police officer. 
there are too few police in large cities. ${ }^{26}$

Given that public welfare spending also appeared to reduce crime in Table 4, it is worth examining the cost-effectiveness of increasing public welfare spending in reducing crime. The mean level of public welfare spending per capita in the sample is $\$ 255$. A one percent increase in public welfare spending for a city with a population of 100,000 would cost $\$ 255,000$. Using the estimated elasticities from Table 4 and the estimates of the cost of crime to victims, the total social value of reduced crime is approximately $\$ 39,000$. Thus, while public welfare spending does not appear cost-beneficial in terms of crime reduction alone, this channel should not be ignored in a broader consideration of the benefits of public welfare spending. ${ }^{27}$

\section{Section VI: Conclusions}

Previous studies have found little systematic evidence that increasing the size of a city's police force lowers the crime rate. By controlling more effectively for unobserved differences across cities and eliminating the simultaneity between police and crime through the use of the timing of mayoral and gubernatorial elections, this paper does uncover evidence that police reduce crime. Estimates of the social costs of crime suggest that current levels of police staffing

26 Another consideration that is ignored in this cost-benefit analysis is the possible change in prison costs associated with the increase in the number of police. As McCormick and Tollison (1984) demonstrate, however, the effect of increasing the number of police on the number of arrests is ambiguous. When the likelihood of detection increases, a greater fraction of the crimes committed result in arrests, but some crimes that would previously have been committed are now successfully deterred and therefore do not lead to arrests. In McCormick and Tollison's data on fouls in the ACC basketball toumament, the number of fouls (arrests) drops substantially when the number of officials (police) is increased.

27 For a thorough analysis of the possible cost-benefit tradeoff implied by a variety of educational and labor market interventions, see Donohue and Siegelman (1994). 
in large cities are below the optimal level. Caution is warranted, however, in extrapolating the findings of this paper to a broader sample of cities. The cities analyzed here have far higher levels of criminal victimization than the nation as a whole; it is likely that the benefits of additional officers will be more limited in a broader sample of cities. The analysis of this paper suggests a number of avenues for future research. The most obvious shortcoming of the current work is the reliance on reported crime statistics. While individual-level victimization data is available, the absence of geographic indicators precludes a straightforward analysis of the relationship between police staffing and victimization. The lack of consensus in existing estimates of the magnitude of the reporting bias (Craig 1987, Levitt 1994) suggests that further work in this area is warranted. A second issued deserving more attention is the extent to which crime spills over between central cities and surrounding suburbs. The analysis presented here focuses exclusively on central cities. It is possible, however, that at least some of the decrease in crime in central cities associated with increased police staffing represents a geographical spillover of crime rather than a true reduction.

The finding that city police hiring is affected by the timing of elections adds to the short, but growing, literature documenting the effects of politics on economic decision-making (e.g., Rogoff 1990, Besley and Case 1994, Poterba 1994). This paper goes beyond those previous works, however, by using the political budget cycle as a source of exogenous variation to identify the value of public expenditures. The approach taken in this paper could in theory be applied to a wide range of public policies at all levels of government, and is likely to lead to more reliable estimates than studies based on either cross-sectional or time-series variation. 
Table 1: Summary Statistics

(All Values per 100,000 residents except population)

\begin{tabular}{|c|c|c|c|c|}
\hline Variable & Mean & $\begin{array}{l}\text { Standard } \\
\text { Deviation }\end{array}$ & $\underline{\text { Minimum }}$ & $\underline{\text { Maximum }}$ \\
\hline Population & 716,692 & $1,030,250$ & 85,000 & $7,896,000$ \\
\hline Total Crimes & 8,902 & 2,586 & 3,105 & 20,690 \\
\hline Violent Crimes & 1,162 & 684 & 103 & 4,353 \\
\hline Murder & 19 & 12 & 0.7 & 81 \\
\hline Rape & 68 & 31 & 4 & 199 \\
\hline Assault & 521 & 353 & 42 & 2,386 \\
\hline Robbery & 554 & 377 & 26 & 2,338 \\
\hline Property Crimes & 7,740 & 2,584 & 3,105 & 20,690 \\
\hline Burglary & 2,307 & 732 & 600 & 4,994 \\
\hline Larceny & 4,364 & 1,403 & 550 & 10,003 \\
\hline $\begin{array}{l}\text { Motor Vehicle } \\
\text { Theft }\end{array}$ & 1,069 & 693 & 165 & 5,369 \\
\hline Overall Police & 294 & 110 & 79 & 910 \\
\hline Sworn & 237 & 99 & 70 & 781 \\
\hline Civilian & 57 & 27 & 5 & 176 \\
\hline
\end{tabular}


Table 2: Summary Statistics for Demographic, Economic, and Spending Controls

Standard Deviation

\begin{tabular}{|c|c|c|c|c|c|}
\hline Variable & Mean & Within-City & Across Cities & $\underline{\text { Minimum }}$ & Mainm \\
\hline \% Black & 23.0 & 2.3 & 18.1 & 0.1 & 78.2 \\
\hline $\begin{array}{l}\text { \% Female Headed } \\
\text { Households }\end{array}$ & 14.9 & 1.0 & 4.3 & 5.6 & 31.9 \\
\hline$\%$ Age $15-24$ & 17.2 & 1.5 & 17.2 & 11.5 & 25.4 \\
\hline $\begin{array}{l}\text { Public Welfare } \\
\text { Spending Per Capita } \\
\text { (1992 dollars) }\end{array}$ & 255.2 & 56.8 & 126.0 & 33.5 & 847.7 \\
\hline $\begin{array}{l}\text { Education } \\
\text { Spending Per Capita } \\
\text { (1992 Dollars) }\end{array}$ & 765.2 & 79.7 & 122.9 & 445.9 & 1193.4 \\
\hline $\begin{array}{l}\text { State } \\
\text { Unemployment Rate }\end{array}$ & 6.5 & 1.8 & 2.0 & 2.0 & 15.5 \\
\hline
\end{tabular}

Notes: Summary statistics are for the 59 large U.S. cities included in the sample for the years 1970-1992. Data on \% Black and \% Female Headed Household are city-level data interpolated from the decennial census. \% Age 15-24 is defined at the SMSA level, and is also based on decennial census. Spending data is combined state and local government spending on an annual basis, and is defined at the state level. See text for further description of data sources. 
(1)

Variable

Mayoral Election Timing

Election Year (2-year Term)

Election Year (4-year Term)

Year Before Election

(4-year terms only)

Two Years Before Election (4-year terms only)

Gubernatorial Election Timing Election Year

Year Before Election (4-year terms only)

Two Years Before Election (4-year terms only)

\% $\Delta$ City Population

$\Delta(\%$ Black $)$

$\Delta(\%$ Female Head $)$

State Unemployment Rate

$\Delta(\%$ Age $15-24$ in SMSA $)$
\% $\Delta$ Total

Police

.014

$(.007)$

.008

$(.005)$

.005

$(.005)$

$-.002$

$(.005)$

.026

$(.008)$

$-.002$

$(.005)$

.004

$(.008)$

.030

(.059)

$-.013$

$(.009)$

.014

(.018)

$-.331$

(.136)

3.131

(2.392)
(2)

\% $\Delta$ Sworn

Officers

.013

$(.007)$

.010

$(.004)$

.007

$(.004)$

$-.001$

(.004)

(3)

$\% \Delta$ Civilian

Employees

.018

(.020)

.000

(.018)

$-.006$

(.018)

$-.003$

(.018)

.015

(.037)

.030

(.008)

$-.009$

(.021)

.001
$(.005)$

$-.034$

(.033)

$(.008)$

.119

(.214)

.005
$(.053)$

$-.014$

(.023)

$(.009)$

$-.088$

(.080)

.018
$(.016)$

$-.413$

(.503)

(.131)

2.92

(2.16)
Year Effects?

Yes

Yes

.05

Significance of Mayoral Election Years?

Significance of All Election Years?

R-Squared
$<.01$

.22

Yes
Yes
.02
$<.01$
21

.21
Yes

Yes

.67

.82

.07

Notes: Sample includes 59 large U.S. cities with directly elected mayors, 1970-1992. Number of observations is 1,275. The omitted election year category in all cases is the year following an election. The effects of elections on police staffing are constrained to be equal across all cities. White heteroskedasticity-consistent standard errors in parentheses. 
Table 4: The Effect of Increased Police on Crime

Instrumenting with Election Cycles and Including Covariates

\begin{tabular}{|c|c|c|c|c|c|c|c|}
\hline & Murder & Rape & Assault & Robbery & Burglary & Larceny & $\begin{array}{l}\text { Vehicle } \\
\text { Theft }\end{array}$ \\
\hline In Sworn Officers & $\begin{array}{l}-.63 \\
(.30)\end{array}$ & $\begin{array}{l}-.46 \\
(.25)\end{array}$ & $\begin{array}{l}. .28 \\
(.26)\end{array}$ & $\begin{array}{l}. .67 \\
(.26)\end{array}$ & $\begin{array}{l}-.11 \\
(.20)\end{array}$ & $\begin{array}{l}.06 \\
(.17)\end{array}$ & $\begin{array}{r}-1.23 \\
(.29)\end{array}$ \\
\hline In Civilian Police & $\begin{array}{l}.05 \\
(.08)\end{array}$ & $\begin{array}{l}.03 \\
(.06)\end{array}$ & $\begin{array}{l}-.03 \\
(.07)\end{array}$ & $\begin{array}{l}.06 \\
.07)\end{array}$ & $\begin{array}{l}-.07 \\
(.06)\end{array}$ & $\begin{array}{l}-.13 \\
(.06)\end{array}$ & $\begin{array}{l}.00 \\
. .07)\end{array}$ \\
\hline In City Population & $\begin{array}{l}.69 \\
. .19)\end{array}$ & $\begin{array}{l}.56 \\
(.14)\end{array}$ & $\begin{array}{l}-.04 \\
(.16)\end{array}$ & $\begin{array}{l}.44 \\
.(15)\end{array}$ & $\begin{array}{l}.19 \\
(.10)\end{array}$ & $\begin{array}{l}.30 \\
. .09)\end{array}$ & $\begin{array}{l}1.09 \\
(.16)\end{array}$ \\
\hline \% Black & $\begin{array}{l}.025 \\
(.008)\end{array}$ & $\begin{array}{l}-.027 \\
(.007)\end{array}$ & $\begin{array}{c}.001 \\
. .008)\end{array}$ & $\begin{array}{l}-.011 \\
(.008)\end{array}$ & $\begin{array}{l}-.014 \\
(.006)\end{array}$ & $\begin{array}{l}.007 \\
(.005)\end{array}$ & $\begin{array}{l}-.051 \\
(.008)\end{array}$ \\
\hline \% Female Headed Households & $\begin{array}{l}.042 \\
(.020)\end{array}$ & $\begin{array}{r}.049 \\
(.016)\end{array}$ & $\begin{array}{l}. .021 \\
. .017)\end{array}$ & $\begin{array}{l}-.000 \\
(.017)\end{array}$ & $\begin{array}{l}. .009 \\
(.013)\end{array}$ & $\begin{array}{l}.017 \\
(.011)\end{array}$ & $\begin{array}{l}.070 \\
(.018)\end{array}$ \\
\hline \% $\triangle \mathrm{Age}$ 15-24 in SMSA & $\begin{array}{l}-2.73 \\
(3.10)\end{array}$ & $\begin{array}{l}-10.05 \\
(2.24)\end{array}$ & $\begin{array}{r}2.34 \\
(2.67)\end{array}$ & $\begin{array}{c}6.75 \\
(2.57)\end{array}$ & $\begin{array}{l}4.19 \\
(1.78)\end{array}$ & $\begin{array}{c}5.23 \\
(1.40)\end{array}$ & $\begin{array}{r}7.40 \\
(2.62)\end{array}$ \\
\hline $\begin{array}{l}\text { In Public Welfare Spending } \\
\text { Per Capita }\end{array}$ & $\begin{array}{l}-.08 \\
(.05)\end{array}$ & $\begin{array}{l}-.11 \\
(.04)\end{array}$ & $\begin{array}{l}-.14 \\
(.04)\end{array}$ & $\begin{array}{l}-.11 \\
(.04)\end{array}$ & $\begin{array}{l}. .07 \\
(.03)\end{array}$ & $\begin{array}{l}. .07 \\
(.03)\end{array}$ & $\begin{array}{l}-.15 \\
(.05)\end{array}$ \\
\hline $\begin{array}{l}\text { In Education Spending } \\
\text { Per Capita }\end{array}$ & $\begin{array}{l}.41 \\
(.12)\end{array}$ & $\begin{array}{l}.25 \\
(.09)\end{array}$ & $\begin{array}{c}.08 \\
(.10)\end{array}$ & $\begin{array}{c}.38 \\
. .11)\end{array}$ & $\begin{array}{l}.33 \\
(.08)\end{array}$ & $\begin{array}{l}.03 \\
(.06)\end{array}$ & $\begin{array}{l}.60 \\
(.11)\end{array}$ \\
\hline State Unemployment Rate & $\begin{array}{l}-2.65 \\
(0.54)\end{array}$ & $\begin{array}{l}-1.84 \\
(0.44)\end{array}$ & $\begin{array}{l}-1.22 \\
(0.49)\end{array}$ & $\begin{array}{l}.11 \\
(.47)\end{array}$ & $\begin{array}{l}2.34 \\
(0.34)\end{array}$ & $\begin{array}{c}1.30 \\
(0.29)\end{array}$ & $\begin{array}{l}.52 \\
(.51)\end{array}$ \\
\hline City-Fixed Effects? & Yes & Yes & Yes & Yes & Yes & Yes & Yes \\
\hline City Trends? & Yes & Yes & Yes & Yes & Yes & Yes & Yes \\
\hline Year Dummies? & Yes & Yes & Yes & Yes & Yes & Yes & Yes \\
\hline
\end{tabular}

Notes: Dependent variable is the natural $\log$ of the named crime category. Police variables, city population, and spending variables are also in natural logs; therefore coefficients on those variables are interpreted as elasticities. The police coefficients are the sum of the coefficients on contemporaneous and once-lagged police. The sample covers the period 1970-1992 for 59 large U.S. cities with directly elected mayors. City-fixed effects, city trends, and year dummies included in all regressions. Number of observations is 1,314. Standard errors in parentheses. All specifications were estimated using FGLS to allow for heteroskedasticity across cities. All regressions are instrumented using interactions between city dummies and indicator variables for the year of the mayoral and gubernatorial election cycle. 
Table 5: Progression of the Estimated Impact of Police on Crime as Controls for Unobserved City Characteristics and Endogeneity are Introduced

Murder $\underline{\text { Rape }} \underline{\text { Assault }} \underline{\text { Robbery }}$ Burglary $\underline{\text { Larceny }} \begin{gathered}\text { Vehicle } \\ \text { Theft }\end{gathered}$

\section{Sworn Officers}

\begin{tabular}{|c|c|c|c|c|c|c|c|}
\hline $\begin{array}{l}\text { City-Fixed Effects, Year } \\
\text { Dummies, and Demographic } \\
\text { Controls Only }\end{array}$ & $\begin{array}{l}.03 \\
(.07)\end{array}$ & $\begin{array}{l}.30 \\
(.07)\end{array}$ & $\begin{array}{l}.51 \\
(.08)\end{array}$ & $\begin{array}{l}.32 \\
(.07)\end{array}$ & $\begin{array}{l}.33 \\
(.05)\end{array}$ & $\begin{array}{l}.27 \\
. .04)\end{array}$ & $\begin{array}{l}.27 \\
(.08)\end{array}$ \\
\hline $\begin{array}{l}\text { All of the Above } \\
\text { and City Trends }\end{array}$ & $\begin{array}{l}-.18 \\
(.10)\end{array}$ & $\begin{array}{l}-.13 \\
(.08)\end{array}$ & $\begin{array}{l}.05 \\
(.09)\end{array}$ & $\begin{array}{l}-.29 \\
(.08)\end{array}$ & $\begin{array}{l}-.18 \\
(.06)\end{array}$ & $\begin{array}{l}.04 \\
(.05)\end{array}$ & $\begin{array}{l}-.37 \\
(.09)\end{array}$ \\
\hline $\begin{array}{l}\text { All of the Above and } \\
\text { Instrument with Elections }\end{array}$ & $\begin{array}{l}-.63 \\
(.30)\end{array}$ & $\begin{array}{l}-.46 \\
(.25)\end{array}$ & $\begin{array}{l}-.28 \\
(.26)\end{array}$ & $\begin{array}{l}-.67 \\
(.26)\end{array}$ & $\begin{array}{l}-.11 \\
(.20)\end{array}$ & $\begin{array}{c}.06 \\
(.17)\end{array}$ & $\begin{array}{r}-1.23 \\
(.29)\end{array}$ \\
\hline
\end{tabular}

\section{Civilian Police Employees}

\begin{abstract}
City-Fixed Effects, Year
Dummies \& Demographic

Controls Only
\end{abstract}

All of the Above
and City Trends

All of the Above and

Instrument with Elections

$\begin{array}{lcccccc}.07 & .10 & .16 & .09 & .02 & .02 & .00 \\ (.03) & (.03) & (.03) & (.03) & (.02) & (.02) & (.03)\end{array}$

$\begin{array}{ccccccc}.12 & .05 & .05 & .16 & -.02 & -.01 & .05 \\ (.03) & (.03) & (.03) & (.03) & (.02) & (.03) & (.03) \\ & & & & & & \\ .05 & .03 & -.03 & .06 & -.07 & -.13 & .00 \\ (.08) & (.06) & (.07) & (.07) & (.06) & (.06) & (.07)\end{array}$

Notes: All coefficients in table are elasticities. The sample is 59 large U.S. cities with directly elected mayors, for the period 1970-1992. Number of observations is 1,314. Within each police staffing category (i.e. sworn and civilian), each row represents coefficients from a different regression with varying levels of controls. Standard errors in parentheses. All specifications were estimated using FGLS, allowing for heteroskedasticity across cities. Elasticities in the bottom row of each category are the coefficients reported in Table 4. 


\begin{tabular}{|c|c|c|c|c|c|c|c|}
\hline & Murder & Rape & Assault & Robbery & Burglary & Larceny & $\begin{array}{l}\text { Vehicle } \\
\text { Theft }\end{array}$ \\
\hline Sworn Officers & $\begin{array}{c}-.34 \\
(.29)\end{array}$ & $\begin{array}{r}-.29 \\
(.24)\end{array}$ & $\begin{array}{c}-.38 \\
(.25)\end{array}$ & $\begin{array}{l}-.62 \\
(.25)\end{array}$ & $\begin{array}{c}. .11 \\
\text { (.20) }\end{array}$ & $\begin{array}{c}.05 \\
(.16)\end{array}$ & $\begin{array}{l}-1.28 \\
(.29)\end{array}$ \\
\hline Civilian Police & $\begin{array}{c}.03 \\
. .09)\end{array}$ & $\begin{array}{c}.02 \\
(.07)\end{array}$ & $\begin{array}{c}-.02 \\
(.06)\end{array}$ & $\begin{array}{r}.09 \\
(.07)\end{array}$ & $\begin{array}{l}-.07 \\
(.06)\end{array}$ & $\begin{array}{r}-.13 \\
(.05)\end{array}$ & $\begin{array}{c}.00 \\
. .07)\end{array}$ \\
\hline City Population & $\begin{array}{c}.75 \\
(.19)\end{array}$ & $\begin{array}{l}.61 \\
. .15)\end{array}$ & $\begin{array}{c}.03 \\
(.16)\end{array}$ & $\begin{array}{r}.47 \\
(.15)\end{array}$ & $\begin{array}{c}.23 \\
. .11)\end{array}$ & $\begin{array}{c}.31 \\
(.09)\end{array}$ & $\begin{array}{l}1.15 \\
(.17)\end{array}$ \\
\hline City-Fixed Effects? & Yes & Yes & Yes & Yes & Yes & Yes & Yes \\
\hline City Trends? & Yes & Yes & Yes & Yes & Yes & Yes & Yes \\
\hline Year Dummies? & Yes & Yes & Yes & Yes & Yes & Yes & Yes \\
\hline
\end{tabular}

Notes: Dependent variable is the natural log of the named crime category. Police variables, city population, and spending variables are also in natural logs; therefore coefficients on those variables are interpreted as elasticities. The police coefficients are the sum of the coefficients on contemporaneous and once-lagged police. The sample covers the period 1970-1992 for the 59 largest U.S. cities with directly elected mayors. City-fixed effects, city trends, and year dummies included in all regressions. Number of observations is 1,314. Standard errors in parentheses. All specifications were estimated using FGLS, allowing for heteroskedasticity across cities. All regressions are instrumented using interactions

$\begin{array}{lcccccccc} & \\ \text { and City Trends } & (.03) & (.03) & (.03) & (.03) & (.02) & (.03) & (.03) \\ & & & & & & & \\ \text { All of the Above and } & .05 & .03 & -.03 & .06 & -.07 & -.13 & .00 \\ \text { Instrument with Elections } & (.08) & (.06) & (.07) & (.07) & (.06) & (.06) & (.07)\end{array}$

Notes: All coefficients in table are elasticities. The sample is 59 large U.S. cities with directly elected mayors, for the period 1970-1992. Number of observations is 1,314. Within each police staffing category (i.e. sworn and civilian), each row represents coefficients from a different regression with varying levels of controls. Standard errors in parentheses. All specifications were estimated using FGLS, allowing for heteroskedasticity across cities. Elasticities in the bottom row of each category are the coefficients reported in Table 4. 
Table 7: Estimated Impact On Crime From Adding One Sworn Police Officer

(Evaluated At Sample Means)

\begin{tabular}{cllll} 
& $\begin{array}{c}\text { Change in Total } \\
\text { Crime (Assumes }\end{array}$ & \multicolumn{2}{c}{ Cost Per Crime } & \\
Change in & $\begin{array}{l}\text { Same Elasticity for } \\
\text { Samed }\end{array}$ & & $\begin{array}{c}\text { Quality } \\
\text { Social Benefit } \\
\text { of Reduced } \\
\text { Crime }\end{array}$
\end{tabular}

$\begin{array}{lccccc}\text { Murder } & -0.05 & -0.05 & \$ 17,000 & \$ 400,000 & \$ 20,800 \\ \text { Rape } & -0.13 & -0.19 & 9,800 & 40,800 & 6,600-9,600 \\ \text { Assault } & -0.6 & -1.3 & 1,800 & 10,200 & 7,400-16,000 \\ \text { Robbery } & -1.6 & -2.9 & 2,900 & 14,900 & 28,700-51,900 \\ \text { Burglary } & -1.1 & -2.3 & 1,200 & 400 & 1,700-3,600 \\ \text { Larceny } & 1.1 & 4.0 & 200 & 0 & (-200)-(-800) \\ \text { Auto Theft } & -5.6 & -7.5 & 4,000 & 0 & 22,500-30,100 \\ & & & & & \\ \text { Total } & -7.98 & -10.24 & --- & -- & 87,500-131,200\end{array}$

Notes: Based on estimates of elasticity of crime with respect to sworn police officers from Table 4 (full controls and election year instruments). Values in table are computed using sample means in 1992. Estimates of reporting rates for each type of crime are based on Criminal Victimization in the United States. 1991 (Wash, DC: U.S. Dept. of Justice, 1992), p. 102. With the exception of the quality of life reduction per murder, estimates of the social costs of crime are from Cohen (1988) and Miller, Cohen, and Rossman (1993), adjusted to 1992 dollars. The first value in the final column applies the cost of crime to the reduction in reported crimes only; the second value in the final column applies the cost of crime to the estimated change in both reported and unreported crimes. 
Figure 1: Trends in Crime and Police

250

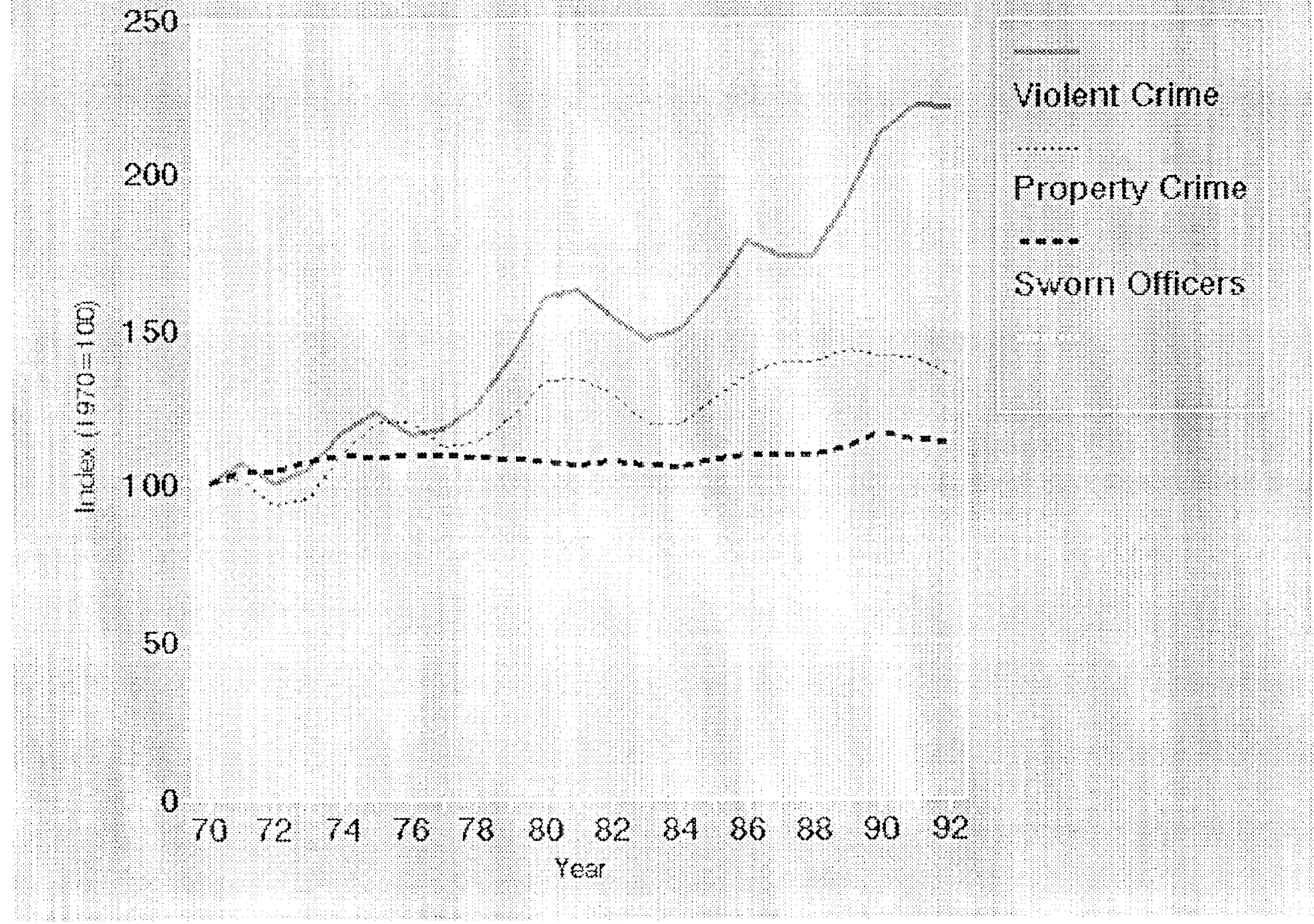




\section{Fig. 2: Yearly Changes in Sworn Police Elextión Years on Fon-Election Years}

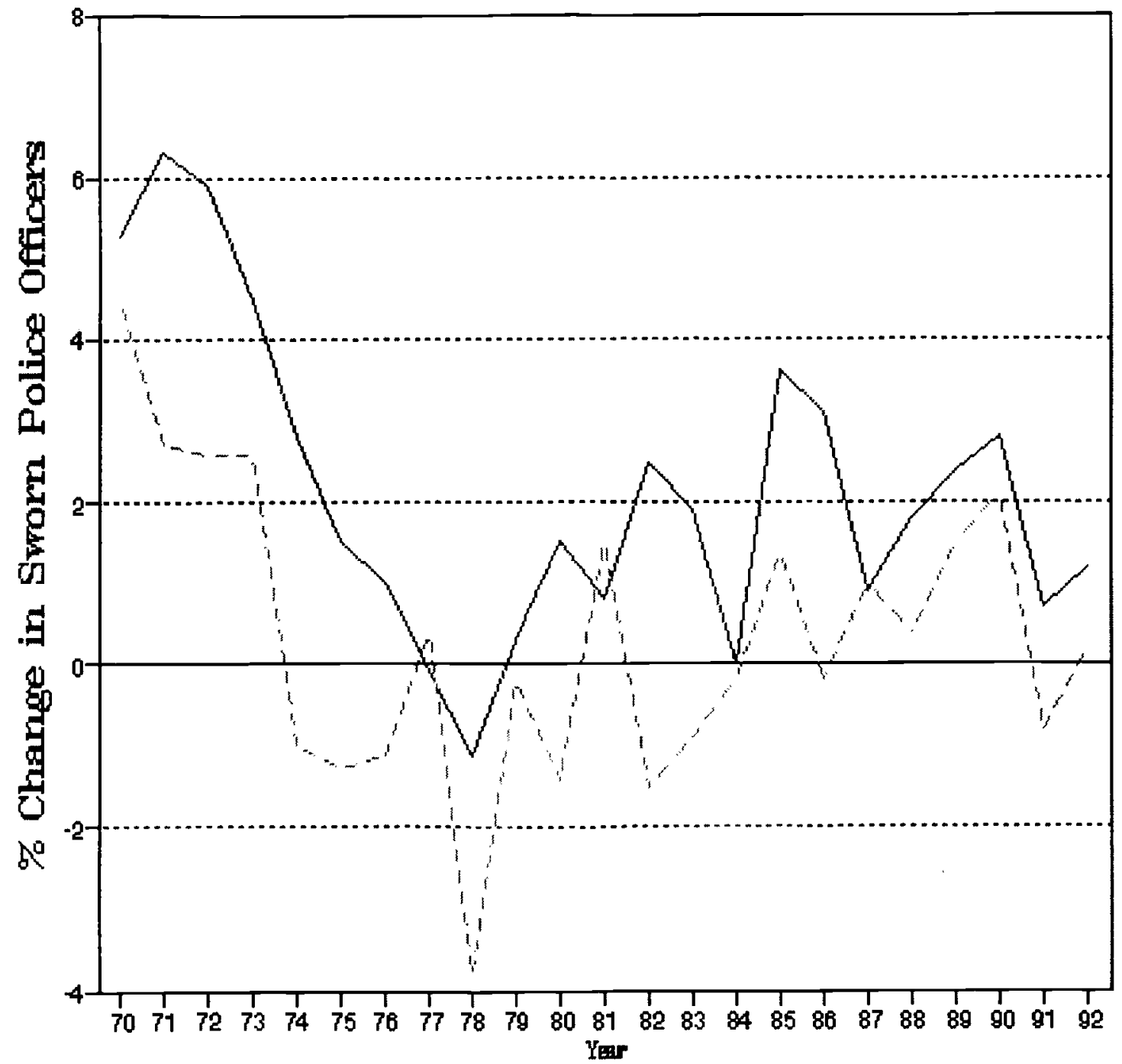

\section{Election year}

Non-election year 
Appendix: Data for Cities in Sample

City

$\% \Delta$ Sworn \% \% Sworn

Term

Per 100.000

Per 100.000

Crime

Per 100.000

Gov, Elec. Mayor Elec.

$\% \Delta$ Sworn

$\begin{array}{llr}\text { Akron } & \text { 4yrs } & 704 \\ \text { Albuquerque } & 4 \mathrm{yrs} & 971 \\ \text { Anaheim } & 2 \mathrm{yrs} & 535 \\ \text { Arlington } & 2 \mathrm{yrs} & 424 \\ \text { Atlanta } & 4 \mathrm{yrs} & 2,417 \\ \text { Austin } & 3 \mathrm{yrs} & 498 \\ \text { Baltimore } & 4 \mathrm{yrs} & 2,031 \\ \text { Birmingham } & 4 \mathrm{yrs} & 1,209 \\ \text { Boston } & 4 \mathrm{yrs} & 1,839 \\ \text { Buffalo } & 4 \mathrm{yrs} & 1,033 \\ \text { Charlotte } & 2 \mathrm{yrs} & 1,264 \\ \text { Chicago } & 4 \mathrm{yrs} & 1,165 \\ \text { Cleveland } & 4 \mathrm{yrs} & 1,468 \\ \text { Columbus } & 4 \mathrm{yrs} & 781 \\ \text { Corpus Christi } & 2 \mathrm{yrs} & 662 \\ \text { Dallas } & 2 \mathrm{yrs} & 1,437 \\ \text { Denver } & 4 \mathrm{yrs} & 906 \\ \text { Detroit } & 4 \mathrm{yrs} & 2,139 \\ \text { El Paso } & 2 \mathrm{yrs} & 680 \\ \text { Fort Worth } & 2 \mathrm{yrs} & 1,118 \\ \text { Fresno } & 4 \mathrm{yrs} & 918 \\ \text { Honolulu } & 4 \mathrm{yrs} & 250 \\ \text { Houston } & 2 \mathrm{yrs} & 940 \\ \text { Indianapolis } & 4 \mathrm{yrs} & 887 \\ \text { Jacksonville } & 4 \mathrm{yrs} & 1,079 \\ \text { Jersey City } & 4 \mathrm{yrs} & 1,271 \\ \text { Kansas City } & 4 \mathrm{yrs} & 1,602 \\ \text { Los Angeles } & 4 \mathrm{yrs} & 1,632 \\ \text { Louisville } & 4 \mathrm{yrs} & 766 \\ \text { Memphis } & 4 \mathrm{yrs} & 1,058 \\ \text { Mesa } & 2 \mathrm{yrs} & 420 \\ \text { Miami } & 4 \mathrm{yrs} & 2,577\end{array}$

6,544
8,151
6,953
6,389
10,634
8,067
6,974
8,235
9,208
6,222
8,199
6,316
6,880
7,516
7,751
10,401
8,780
9,071
6,715
10,311
10,126
5,865
7,529
5,647
7,079
6,102
8,341
7,250
5,488
6,861
6,510
10,567

3.6

204

1.2

0.6

$-0.3$

255

186

2.6

6.3

$-0.1$

3.2

2.1

8.1

7.2

369

2.3

4.8

$2.7 \quad 219$

7.4

$-1.1$

3.5

$-1.7$

$3.2 \quad 286$

3.1

0.2

$-9.8$

$-5.1$

$-1.5$

3.4

2.7

3.5

3.5

3.0

3.0

1.1

10.6

6.2

5.0

6.8

4.5

5.3

1.4

4.3

4.5

4.3

2.6

$-1.6$

$-0.9$

11.7

4.3

$0.7 \quad 320$

2.0

243

329

9.4

2.5

$-0.1$ 
Appendix: Data for Cities in Sample

\begin{tabular}{|c|c|c|c|c|c|c|c|c|}
\hline City & $\begin{array}{c}\text { Mayor's } \\
\text { Term }\end{array}$ & $\begin{array}{l}\text { Violent Crimes } \\
\text { Per } 100.000\end{array}$ & $\begin{array}{l}\text { Property Crimes } \\
\text { Per } 100.000\end{array}$ & $\begin{array}{l}\text { Annual } \\
\text { Crime }\end{array}$ & $\begin{array}{lr}8 \Delta & \text { Police } \\
\text { Per } 100.000 \\
\end{array}$ & 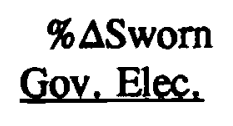 & $\begin{array}{r}\% \Delta \text { Swom } \\
\text { Mayor Elec. }\end{array}$ & $\begin{array}{l}\% \Delta \text { Swom } \\
\text { No Elec. }\end{array}$ \\
\hline Milwaukee & $4 \mathrm{yrs}$ & 580 & 6,051 & 3.4 & 360 & -0.4 & 1.2 & 0.7 \\
\hline Minneapolis & 4 yrs & 1,102 & 8,417 & 2.3 & 225 & -0.1 & 1.8 & 0.3 \\
\hline Nashville & $4 \mathrm{yrs}$ & 857 & 6,044 & 3.1 & 245 & 3.6 & 2.1 & 4.2 \\
\hline Newark & $4 y r s$ & 2,709 & 8,736 & 1.8 & 431 & 11.4 & -2.6 & -6.0 \\
\hline New Orleans & $4 \mathrm{yrs}$ & 1,419 & 7,140 & 1.4 & 321 & 4.5 & -2.0 & -1.0 \\
\hline New York & $4 y r s$ & 1,902 & 6,594 & 0.7 & 441 & 2.8 & 1.0 & 1.0 \\
\hline Oakland & $4 y r s$ & 1,753 & 10,318 & 0.2 & 267 & -2.6 & -2.6 & 2.1 \\
\hline Oklahoma City & $4 y r s$ & 845 & 8,160 & 3.3 & 217 & 6.3 & 6.3 & 2.6 \\
\hline Omaha & $4 y r s$ & 655 & 5,743 & 1.4 & 201 & 2.0 & 1.2 & 0.5 \\
\hline Phoenix & $4 y r s$ & 797 & 8,889 & 0.3 & 264 & 3.5 & 5.6 & 3.4 \\
\hline Philadelphia & $4 y r s$ & 942 & 4,162 & 2.8 & 469 & 1.9 & -2.9 & -0.8 \\
\hline Pittsburgh & $4 y r s$ & 1,100 & 5,939 & 1.2 & 319 & -2.4 & -0.8 & -2.1 \\
\hline Portland & $4 y r s$ & 1,521 & 10,557 & 1.3 & 240 & 3.2 & 1.5 & -0.9 \\
\hline Sacramento & $4 y r s$ & 1,018 & 9,147 & 1.1 & 247 & 2.9 & 0.4 & 2.6 \\
\hline Saint Louis & $4 y r s$ & 2,181 & 10,235 & 1.2 & 507 & -0.9 & -0.7 & -1.1 \\
\hline Saint Paul & $4 y r s$ & 756 & 6,883 & 0.9 & 233 & -2.8 & 1.2 & 3.3 \\
\hline Saint Petersburg & $2 y r s$ & 1,209 & 7,254 & 1.9 & 257 & 5.2 & 2.4 & -0.6 \\
\hline San Antonio & $2 \mathrm{yrs}$ & 582 & 8,213 & 2.5 & 181 & 7.6 & 0.5 & 1.5 \\
\hline San Diego & $4 y r s$ & 676 & 6,927 & 1.6 & 199 & 7.1 & 4.3 & 1.7 \\
\hline San Francisco & 4yrs & 1,454 & 7,959 & -0.0 & 333 & -1.2 & 0.9 & 1.8 \\
\hline San Jose & $4 \mathrm{yrs}$ & 497 & 6,083 & -1.6 & 167 & 7.1 & 7.1 & 3.5 \\
\hline Seattle & $4 y r s$ & 1,026 & 9,488 & 1.6 & 285 & 1.7 & 0.0 & 1.6 \\
\hline Tampa & $4 \mathrm{yrs}$ & 1,868 & 10,444 & 4.0 & 300 & 7.1 & 0.3 & 0.0 \\
\hline Toledo & $2 \mathrm{yrs}$ & 728 & 7,408 & 1.4 & 211 & -2.6 & 2.8 & -5.2 \\
\hline Tucson & $4 y r s$ & 695 & 8,938 & 2.7 & 218 & 3.9 & 4.3 & 4.5 \\
\hline Tulsa & 2 yrs & 741 & 7,076 & 2.1 & 214 & 2.2 & 2.1 & 1.7 \\
\hline Washington DC & $4 y r s$ & 1,890 & 7,101 & 0.2 & 739 & -- & -2.2 & -1.8 \\
\hline
\end{tabular}




\section{Definitions of the Uniform Crime Reports Crime Categories}

Murder and Nonnegligent Manslaughter

The willful killing of one human being by another. Deaths caused by negligence, attempts to kill, assaults to kill, suicides, accidental deaths, and justifiable homicides are excluded. Justifiable homicides are limited to the killing of a felon. Traffic fatalities are excluded.

Forcible Rape

The carnal knowledge of a female forcibly and against her will. Included are rapes by force and attempts or assaults to rape. Statutory offenses (no force used -- victim under age of consent) are excluded.

Robbery

The taking or attempting to take anything of value from the care, custody, or control of a person or persons by force, or threat of force, or violence, and/or by putting the victim in fear.

Aggravated Assault

An unlawful attack by one person upon another for the purpose of inflicting severe or aggravated bodily injury. This type of assault usually is accompanied by the use of a weapon or by means likely to produce death or great bodily harm. Simple assaults are excluded.

Burglary

The unlawful entry of a structure to commit a felony or a theft. Attempted forcible entry is included.

Larceny

The unlawful taking of property from the possession of another. Examples are thefts of bicycles or automobile accessories, shoplifting, pocket-picking, or the stealing of any property or article which is not taken by force and violence or by fraud. Attempted larcenies are included. Embezzlement, "con" games, forgery, and worthless checks are excluded.

Motor Vehicle Theft

The theft or attempted theft of a motor vehicle. 


\section{Bibliography}

Alesina, Alberto, and Jeffrey Sachs, 1988, "Political Parties and the Business Cycle in the United States," Journal of Money, Credit, and Banking 20:63-82.

Andreoni, James, 1991, "Reasonable Doubt and the Optimal Magnitude of Fines: Should the Penalty Fit the Crime?" RAND Journal of Economics 22:385-395.

Becker, Gary, 1968, "Crime and Punishment: An Economic Approach," Journal of Political Economy 76:169-217.

Besley, Timothy, and Anne Case, 1994, "Does Electoral Accountability Affect Economic Policy Choices? Evidence from Gubernatorial Term Limits," Mimeo, Department of Economics, Princeton University.

Cameron, Samuel, 1988, "The Economics of Crime Deterrence: A Survey of Theory and Evidence," Kyklos 41:301-323.

Cantor, David, and Kenneth C. Land, 1985, "Unemployment and Crime Rates in the PostWorld War II United States: A Theoretical and Empirical Analysis," American Sociological Review 50:317-332.

Chubb, John, 1988, "Institutions, the Economy, and the Dynamics of State Elections," American Political Science Review 82:135-154.

Cohen, Mark, 1988, "Pain, Suffering, and Jury Awards: A Study of the Cost of Crime to Victims," Law and Society Review 22:537-555.

Craig, S., 1987, "The Deterrent Impact of Police: An Examination of a Locally Provided Public Service," Journal of Urban Economics 21:298-311.

Devine, Joel A., Joseph F. Sheley, and M. Dwayne Smith, "Macroeconomic and SocialControl Policy Influences on Crime Rate Changes, 1948-1985," American Sociological Review 53:407-420.

Donohue, John J., and Peter Siegelman, 1994, "Is the United States at the Optimal Rate of Crime?" Mimeo, American Bar Foundation.

Ehrlich, Isaac, 1973, "Participation in Illegitimate Activities: A Theoretical and Empirical Investigation," Journal of Political Economy 81:531-567.

Fisher, Franklin, and D. Nagin, 1978, "On the Feasibility of Identifying the Crime Function in a Simultaneous Equations Model of Crime and Sanctions," in Blumstein, A., Nagin, D., and Cohen, J. (eds.), Deterrence and Incapacitation: Estimating the Effects of Criminal Sanctions on Crime Rates, Wash D.C.: National Academy of Sciences. 
Glaeser, Edward, Bruce Sacerdote, and Jose Scheinkman, 1994, "Crime and Social Interactions," Mimeo, Harvard University.

Greene, Jack, and Carl Klockars, 1991, "What Police Do," in Klockars, C., and Mastrofski, S. (eds.), Thinking About Police, New York: McGraw-Hill.

Kelling, George, Tony Pate, Duane Dieckman, and Charles Brown, 1974, The Kansas City Preventative Patrol Experiment: A Summary Report, Wash DC: Police Foundation.

Levitt, Steven, 1994, "The Response of Crime Reporting Behavior to Changes in the Size of the Police Force: Implications for Studies of Police Effectiveness using Reported Crime Data," Mimeo, M.I.T. Department of Economics.

McCormick, Robert, and Robert Tollison, 1984, "Crime on the Court," Journal of Political Economy 92:223-235.

Miller, Ted, Mark Cohen, and Shelli Rossman, 1993, "Victim Costs of Violent Crime and Resulting Injuries," Health Affairs XX:186-197.

Monkkonen, Eric, 1992, "History of Urban Police," in Tonry, M., and Morris, N. (eds.), Modern Policing, Chicago: University of Chicago Press.

Myers, S., 1983, "Estimating the Economic Model of Crime: Punishment vs. Deterrent Effects," Quarterly Journal of Economics 98:157-166.

O'Brien, Robert, 1985, Crime and Victimization Data, Beverly Hills: Sage.

Poterba, James, 1994, "State Responses to Fiscal Crises: The Effects of Budgetary Institutions and Politics," Joumal of Political Economy 102:799-821.

Rogoff, Kenneth, 1990, "Equilibrium Political Budget Cycles," American Economic Review 80:21-36.

Schelling, Thomas, 1989, "Value of Life," in Eatwell, J, Milgate, M., and Newman, P. (eds), The New Palgrave, New York: Norton.

Sherman, Lawrence, 1992, "Attacking Crime: Police and Crime Control," in Tonry, M., and Morris, N. (eds), Modern Policing, Chicago: University of Chicago Press.

Staiger, Douglas, and James Stock, 1993, "Asymptotics for Instrumental Variables Regressions with Weakly Correlated Instruments," Mimeo, Kennedy School of Government, Harvard University

Stigler, George, 1970, "The Optimum Enforcement of Laws," Journal of Political Economy 78:526-536. 
Tauchen, Helen, Anne Witte, and Harriet Griesinger, 1993, "Criminal Deterrence: Revisiting the Issue with a Birth Cohort," Mimeo, Department of Economics, University of North Carolina at Chapel Hill.

Wilson, James Q., 1983, Thinking About Crime, New York: Random House.

Witte, Ann, 1980, "Estimating the Economic Model of Crime with Individual Data," Quarterly Journal of Economics $94: 57-84$ 